\title{
NOSTALGIA I INNE OPOWIADANIA NADIEŻDY TEFFI, CZYLI ROSJANIE W PARYŻU LAT 20. XX WIEKU
}

\section{NOSTALGIA AND OTHER SHORT STORIES BY NADIEZDHA TEFFI, OR RUSSIANS IN PARIS OF THE 1920S}

\author{
NEL BIELNIAK
}

\begin{abstract}
AвsтRACт. In her humorous 1920s short stories Teffi shows the dramatic situation of Russian diaspora in Paris mainly through the prism of ordinary emigrants. The writer pays attention, among others, to such issues connected with the life of refugees as isolation, alienation, poverty, prurient nostalgia or national identity.
\end{abstract}

Keywords: Teffi, emigration, nostalgia, national identity, Russian Paris

Nel Bielniak, Uniwersytet Zielonogórski, Zielona Góra - Polska, nel.bielniak@wp.pl

ORCID ID: 0000-0002-5101-1629

Teffi, a właściwie Nadieżda Aleksandrowna Buczyńska de domo Łochwicka, funkcjonuje w powszechnej świadomości przede wszystkim jako autorka popularnych miniatur i felietonów o zabarwieniu humorystycznym, które z równą przyjemnością czytali zarówno prości obywatele, jak i sam car Nikołaj II. Ukazywały się one między innymi w tygodnikach satyrycznych „Satirikon” („Сатирикон”) i „Nowyj Satirikon” („Новый Сатирикон”), wyróżniających się na tle ówczesnej prasy wysokim poziomem wydawniczym, jak też w oddzielnych zbiorach. Już dwa pierwsze tomy opowiadań humorystycznych (Юмористические рассказы), które zostały opublikowane kolejno w 1910 i 1911 roku, sprawiły, że w przedrewolucyjnej Rosji zaczęto nazywać pisarkę „królową śmiechu”. Nie należy jednak zapominać, że te wczesne humoreski ilustrujące ludzkie niedostatki i absurdy życia codziennego nie były pozbawione, o czym często zdawali się zapominać czytelnicy, akcentów żałości, melancholii czy goryczy. Na swoistą wielopłaszczyznowość czy złożoność utworów Tefii zwraca uwagę Stanisław Nikonienko, który konstatuje:

Они многослойны, многогранны и, в зависимости от того, какой стороной повернутся к внутреннему миру читателя, - вызывают и соответствующую реакцию, потому что где-то в глубине, за словами, репликами персонажей, за представленной в рассказе ситуацией кроется большой мир человеческих чувств и переживаний [Никоненко]. 
Podobną heterogenicznością wyróżniają się teksty autorki Kobiety demonicznej powstałe na wygnaniu. Ścieżki życia Teffi w dużym stopniu przypominają bowiem koleje losu ogromnych rzesz jej rodaków (szacowanych w zależności od źródeł na kilkaset tysięcy lub kilka milionów), którzy po przewrocie bolszewickim opuścili ojczyznę [Ndiaye 2007: 77; Sałajczykowa 2003: 14]. Pisarka wybrała drogę na południe: przez Kijów, Odessę, Noworosyjsk i Konstantynopol, by na początku 1920 roku znaleźć się w Paryżu, który stał się jednym z ważniejszych europejskich centrów rosyjskiej diaspory. Można by rzec, że szczęście jej sprzyjało, zwłaszcza na gruncie zawodowym. Tuż po przyjeździe do stolicy Francji Teffi zaczęła aktywnie uczestniczyć w życiu literackim i kulturalnym rosyjskiej emigracji: otworzyła salon literacki, w którym bywali Iwan Bunin, Władimir Nabokow-starszy, Don-Aminado (właśc. Aminad Pietrowicz vel Aminodaw Pejsachowicz Szpolanski), Tichon Polner, Aleksiej Tołstoj z żoną Natalią Krandijewską czy malarz Aleksander Jakowlew [Зверев 2003], współpracowała ponadto z licznymi czasopismami, wydawała zbiorki opowiadań i wierszy, wystawiała cieszące się dużą popularnością sztuki, brała udział w różnego rodzaju spotkaniach, wieczorkach, dyskusjach etc. Warto nadmienić, że jej działalność nie ograniczała się do ojczyzny Balzaka. Pisarka występowała w Brukseli, Londynie i Warszawie, publikowała w Berlinie i Rydze, a jej utwory sceniczne publiczność mogła oklaskiwać, oprócz wspomnianych tu miast, także w Belgradzie, Pradze, Sofii czy Szanghaju [Нитраур 1989: 10-11, 17].

Niemniej sława nie uchroniła autorki Passiflory od problemów, z jakimi borykała się większość emigrantów. Nieobce były jej kłopoty mieszkaniowe i finansowe, jak też samotność (zwłaszcza po śmierci partnera życiowego w 1935 roku), zwątpienie, poczucie wyobcowania, a nade wszystko tęsknota za krajem ojczystym. Przyczyn takiego stanu ducha należy zapewne upatrywać w niknącej z roku na rok nadziei na powrót do domu i jednocześnie narastającym przekonaniu, że dawna Rosja odeszła na zawsze. Doskonałą egzemplifikacją powyższych słów będzie fragment korespondencji do przyjaciela-,„satirikonca". Oto co Teffi napisała w jednym z listów do Dona-Aminado': „Хочу переменить ремесло. Литературой жить больше нельзя. Невыгодно и скучно. Внешне живу чудесно. Катаюсь по Франции в автомобиле. Чего мне еще надо? А вот все надоело" [2016: 62].

Od pierwszych dni we Francji, w której pobyt miał być w przekonaniu pisarki tylko tymczasowy, a w rzeczywistości potrwał ponad trzy dekady, Teffi uważnie przypatrywała się współtowarzyszom niedoli, a swoje celne, nie-

1 Żaden z opublikowanych przez Natalię Żełtową listów nie był oznaczony datą. Rosyjska badaczka przypuszcza, że najwcześniejsze zostały napisane w 1920 roku, a ostatnie w latach 1930. Wskazują na to nieliczne zachowane stemple pocztowe [Письма Н. А. Тэффи 2016: 63]. 
rzadko ironiczne spostrzeżenia utrwalała w miniaturach. Uwypuklanie niedostatków i śmiesznostek bohaterów nie przeszkadzało jej jednak dostrzegać dramatycznego położenia rosyjskich emigrantów zgodnie z wyartykułowaną w opowiadaniu Смешное b печальном (1920) zasadą: „Время мы переживаем тяжелое и страшное. Но жизнь, сама жизнь по-прежнему столько же смеется, сколько плачет. Ей-то что!" [Тэффи 2011]².

Ta dewiza zdawała się przyświecać Teffi także podczas tworzenia utworów wchodzących w skład zbiorków Рысъ i Городок, w których można odnaleźć tyleż motywów zabawnych, co przygnębiających. Pierwszy z nich ukazał się w Berlinie w 1923 roku, drugi natomiast, zawierający kilka tekstów opublikowanych jeszcze w Rosji, został wydany w Paryżu cztery lata później. Zasygnalizowana wcześniej, typowa dla Teffi, synteza pierwiastków komicznego i tragicznego jest, zdaniem Joanny Mianowskiej, najbardziej symptomatyczną cechą całej rosyjskiej emigracyjnej literatury satyrycznej [Мяновска 2014: 221-222].

Specyfikę kilkudziesięciotysięcznej rosyjskiej enklawy w Paryżu, mieszczącej się w głównej mierze w rejonie Passy oraz na lewym brzegu Sekwany, pisarka znakomicie uchwyciła w opowiadaniu Городок (1927), któremu nadała znamienny podtytuł Хроника. Wskazała w nim warunki bytowania uchodźców, zajęcia, jakimi się parali, a także ich przekrój społeczny. Z utworu Teffi wyłania się obraz hermetycznego środowiska, które przeświadczone o rychłym powrocie do ojczyzny niechętnie odnosiło się do kwestii asymilacji, dlatego też zakładało własne cerkwie, teatry, sklepy, a przede wszystkim jadłodajnie i szynki. Mieszkańców tytułowego miasteczka wyróżnia roszczeniowa postawa, a także niechęć zarówno do pobratymców („Жители городка любили, когда кто-нибудь из их племени оказывался вором, жуликом или предателем"), jak i obywateli kraju, który udzielił im schronienia, co przejawiało się między innymi w lekceważącym nazywaniu Sekwany „иxняя Невка". Paryżanie natomiast, konstatuje autorka, patrzyli na przybyszy jak na wymierające plemię, po którego wielkiej kulturze właściwie nie zostało już śladu. Potomkowie wybitnych ludzi, nierzadko arystokraci, ministrowie, generałowie zajmowali się teraz bowiem głównie chałupnictwem lub szoferką. Wypada zaznaczyć, że do uwypuklonych w tym utworze wątków będzie Teffi jeszcze nie raz wracać.

Implikacją zamkniętości, nieumiejętności i (a może głównie) braku chęci przystosowania się do nowych warunków, ostracyzmu i skierowanych wciąż na Wschód myśli jest, jak przekonuje pisarka, nasilająca się i zakłócająca nor-

${ }^{2}$ Wszystkie cytowane utwory Teffi pochodzą z pięciotomowego zbioru dzieł pisarki, który ukazał się w Moskwie w 2011 roku. Ze względu na posiłkowanie się jego wersją elektroniczną dalej $\mathrm{w}$ tekście głównym nie podajemy w przypisach adresu bibliograficznego po kolejnych cytatach - N. B. 
malne egzystowanie dotkliwa tęsknota za domem ojczystym. Świadczą o tym dowodnie już same tytuły niektórych jej utworów: Вспоминаем (1920), Осколки (1925), Сладкие воспоминания (1925), Тоска (1920) сzy wreszcie Ностальгия (1920). Teffi, co istotne, postrzega ten nieodłączny element uchodźczego losu nierzadko w kategoriach negatywnych. Przemawia za tym otwierające zbiorek Pысь motto z Biblii: „Не говори: «отчего это прежние дни были лучше нынешних?», потому что не от мудрости ты спрашиваешь об этом". Pisarka, odwołując się do starotestamentowej Księgi Koheleta [Koh 7, 10], podkreśla, że w życiu jest czas na wszystko: na szczęście i na rozpacz, na radość i cierpienie, należy jednak zachowywać między nimi równowagę, bo tylko taka postawa pozwala doświadczyć pełni ludzkiego bytu. Jej bohaterowie, rzuceni w odmienną przestrzeń socjokulturową, skupieni są jednak przede wszystkim na rozpamiętywaniu niedalekiej przeszłości. W opowiadaniu Hoстальгия Teffi podaje niezwykle trafną i przenikliwą definicję tytułowego fenomenu:

Тускнеют глаза, опускаются вялые руки и вянет душа - душа, обращенная на восток.

Ни во что не верим, ничего не ждем, ничего не хотим. Умерли.

Боялись смерти большевистской - и умерли смертью здесь.

Вот мы - смертью смерть поправшие.

Думаем только о том, что теперь там. Интересуемся только тем, что приходит оттуда.

А ведь здесь столько дела. Спасаться нужно и спасать других. Но так мало осталось и силы и воли.

Pisarka utożsamia taką kondycję psychiczną ze stanem chorobowym i konstatuje, że w środowisku rosyjskich emigrantów symptomy tej dolegliwości można dostrzec coraz częściej. Warto w tym miejscu zauważyć, że stawianie znaku równości między nostalgią a chorobą nie jest bynajmniej bezpodstawne. Jako pierwszy terminu „nostalgia” (z greckiego nóstos - powrót i álgos - cierpienie) użył bowiem w roku 1688 szwajcarski lekarz Johannes Hofer w swojej dysertacji (Dissertatio medica de Nostalgia, oder Heimwehe, 1688) traktującej o schorzeniach szwajcarskich żołnierzy służących w wojskach zaciężnych z dala od ojczyzny, których stan zdrowia polepszał się wkrótce po powrocie kraju. Dlatego też przez pewien czas nostalgię nazywano nawet szwajcarską chorobą (Schweizerkrankheit). Mimo iż z biegiem czasu termin ten nabrał nowych znaczeń i znalazł się w centrum zainteresowania różnych dziedzin nauki: psychologii, socjologii, filozofii czy literaturoznawstwa, to postrzeganie nostalgii jako choroby przetrwało aż do drugiej połowy XX wieku [Stownik wyrazów obcych 1980: 515; Pietikainen 2015: 177; Меримерина 2009: 135-138]. 
W analizowanym opowiadaniu autorka wyraźnie wskazuje, że ta przypadłość dotyka przedstawicieli wszystkich warstw społecznych i zawodowych, w tym także jej kolegów po piórze, co wyjaśnia użycie w charakterze epigrafu cytatu z wiersza Lolo (właśc. Leonid Munstein) zatytułowanego Пыль Москвы (1920): „Пыль Москвы на ленте старой шляпы / Я как символ свято берегу...". Oczywiście myśli o podobnym zabarwieniu odnaleźć można w twórczości wielu uchodźców: Gieorgija Adamowicza, Dona-Aminado, Arkadija Awierczenki, Iwana Bunina, Mariny Cwietajewej itd. Nagminność tęsknych motywów we wszelkiego rodzaju publikacjach skłoniła Teffi do napisania ironicznego utworu wierszowanego Tocka, który podczas pierwszego wydania w gazecie „Swobodnyje mysli” („Свободные мысли”) także nosił tytuł Ностальгия. Pisarka kpi w nim z emigrantów, u których nostalgia przejawia się w narzekaniu i przesiadywaniu w rosyjskich barach i restauracjach:

Ведь чтоб так - извините - жрать, Нужно действительно за родину-мать

Глубоко страдать!

Nie szczędzi również znajomych ze środowiska twórczego:

Тоскуют писатели наши и поэты,

Печатают в газетах статьи и сонеты

О милом былом,

Сданном на слом.

Lolo хочет снова московских колоколен,

Без колоколен Lolo совсем болен.

Аверченко, как жуир и франт,

Требует восстановить прежний прейскурант [...].

Поет Аминадо печальные песни:

Аминадо, хоть тресни,

Хочется жить на Пресне.

И публицисты, и журналисты,

И лаконичны, и цветисты,

Пишут, что им нужен прежний быт,

Когда каждый был одет и сыт.

(Милые! Уж будто в самом деле

Все на Руси сколько хотели,

Столько ели?)

Cechą charakterystyczną cierpiących na nostalgię uchodźców jest między innymi ich zgaszony wzrok, co zostało uwypuklone przez Teffi w cytowanym wyżej fragmencie opowiadania Ностальгия, jak też w utworze Две встречи (1920), którego bohaterka ma „тусклые, усталые глаза”, oraz w miniaturze Сырье (1920), w której termin nostalgia został zamieniony na „Великая Печаль". W wydanych w 1931 roku Wspomnieniach (Воспоминания), ukazują- 
cych ucieczkę pisarki na Zachód, również można odnaleźć konstatację w podobnym tonie: „У всех нас, отъезжающих, было много печали, и общей всем нам, и у каждого своей, отдельной. Где-то глубоко за зрачками глаз чуть светился знак этой печали, как кости и череп на фуражке «гусаров смерти». Но никто не говорил об этой печали" [Тэффи 1989: 276]. Со сіеkawe, analogiczne skojarzenia pojawiają się w liryce Cwietajewej z początku lat 20. XX wieku, która powstała kilka miesięcy przed wyjazdem do Berlina. Rosyjska badaczka analizująca motyw tęsknoty za ojczyzną w poezji autorki Łabędziego obozu łączy go z ideą wspólnoty wszystkich przymusowych przesiedleńców, która wybrzmiała między innymi w cyklu wierszy Młodzieniec (Отрок, 1921). Cwietajewa, utożsamiając się z losami biblijnej Hagar, antycypowała niejako swoje przyszłe tułacze życie, a stan ducha emigrantów zobrazowała przy pomocy sugestywnej metafory „грустноглазый твой, чужой народ" [Старостина 2010: 310-311] ${ }^{3}$.

Psycholodzy zgłębiający proces socjalno-psychologicznej adaptacji emigrantów pierwszej fali zwracają uwagę na jego cechy szczególne, do których, oprócz zjawiska nostalgii, zaliczają jeszcze stan rozdwojenia, poczucie odrzucenia i upokorzenia czy też przeświadczenie o partycypowaniu w kulturze rosyjskiej [Хрусталева 1999].

Stan swoistej bipartycji, będący rezultatem rozziewu pomiędzy realnym miejscem człowieka w strukturze społecznej kraju, w którym się znajduje, a pewnymi wyidealizowanymi, skierowanymi w przeszłość wyobrażeniami, zarówno własnymi, jak i najbliższego otoczenia, został przez Teffi przedstawiony w opowiadaniach Доктор Коробка (1925), Гедда Габлер (1927) і День (1925). Bohater pierwszego utworu to oderwany od rzeczywistości, od dwudziestu lat niepraktykujący lekarz, który na emigracji postanowił wrócić do zawodu, oczywiście z marnym skutkiem. Korobka ignoruje zmianę swojego statusu społecznego, mówi o sobie bowiem nie „byłem”, lecz „jestem ziemianinem". Z podobną sytuacją mamy do czynienia w kolejnym opowiadaniu nawiązującym do słynnej sztuki Henrika Ibsena. Madame Elise d'Ivanoff,

\footnotetext{
${ }^{3}$ Inną interpretację wierszy z tego cyklu, którego adresatem jest młody poeta, mieszkający latem 1921 roku w domu autorki Poematu końca, proponuje Halina Mazurek. Badaczka podkreśla, że Emilij Mindlin lubił siadywać przy rozgrzanym piecu i spoglądać w ogień, dlatego w poświęconych mu wierszach Cwietajewa skupiła się właśnie na jego oczach. „Patrzenie w ogień, jak mówią kolejne liryki cyklu, wzmaga intensywność wyobrażeń o przyszłym obfitującym w niezwykłe zdarzenia życiu. Sama Cwietajewa zaś, patrząc w oczy młodego poety, chce choć na chwilę przejąć ich żar, zarazić się młodością, zachwycić wyrażaną przez nie gotowością do przyjęcia wyczekiwanych bogatych przeżyć. Porównuje siebie do biblijnej Hagar, by podkreślić zarówno krótką chwilę trwania, jak i siłę pragnienia przebywania z niewinną jeszcze młodością i patrzenia jej w oczy, na razie jeszcze „oczy - pustynie”, ale w których blasku widać „orły, księżyc, zorze, dzieje całego smutnookiego narodu", z którego wywodził się Mindlin" [Mazurek 2014: 166].
} 
czyli po prostu krawcowa Olga Iwanowa, przytłoczona szarą emigracyjną codziennością marzy o twórczym samorozwoju, a swoje frustracje wyładowuje na przypadkowych osobach. Przed klientkami gra rolę erudytki i znawczyni sztuki, peroruje o Antonie Rubinsteinie, Władimirze Sołowiowie, Annie Pawłowej, Diego Velázquezie, lecz jej próby nadania życiu barw i intelektualnego wyrazu są żałosne. Górnolotnie przemowy nie współgrają bowiem z warunkami bytowymi i aparycją bohaterki. W mieszkaniu estetki panuje bałagan, na stoliku pośród pomiętych gazet można znaleźć zarówno brudne sztućce, śledzie, jak i filcowe pantofle. Sama zaś madame Iwanowa wygląda tak:

Большая, толстая, в туфлях на босу ногу, в удивительной меховой кофточке, такой драной и обтертой, что она казалась в ней зверем, только что ушедшим от погони, и которому собаки успели задать здоровую всклычку.

Волосы у мадам д-Ивановой были распущены нечесаными прядями, а на затылке торчала железная шпилька.

Natomiast bohater ostatniego opowiadania, w którym ironia ustępuje miejsca gorzkiej refleksji, były generał carskiej armii, ranny w ramię i kolano, pędzi w Paryżu nędzny żywot: mieszka w lichym pokoiku, żywi się suchym chlebem i serem. Przeraźliwie samotny i wycieńczony ciężką pracą fizyczną pragnie choć na moment przywrócić dawną świetność. Dlatego też w dniu imienin zostaje $\mathrm{w}$ domu, wykonuje staranną toaletę, ubiera się $\mathrm{w}$ mundur haftowany złotem z czerwonymi wypustkami i lampasami, przypina do niego ordery i czeka na gości, którzy jednak nie przychodzą.

Odnotowane przez pisarkę ciężkie warunki socjalno-bytowe sprzyjały powstawaniu poczucia wyobcowania i niesprawiedliwości, wielkie nadzieje emigrantów szybko zamieniły się bowiem w jeszcze większe rozczarowania. Nie może zatem dziwić, że w utworach Teffi wielokrotnie pojawiają się konstatacje, że Rosjanie nie pasują do Paryża, mają bowiem całkiem inną mentalność: „Переведите русскую душу на французский язык” (Ностальгия), czują się w nim ponadto „словно бедная родственница, попавшая в богатый дом на именины" (Сырье), a problemy miejscowych ich nie dotyczą (Мертвый сезон, 1920). Zdarza się także, że tragiczna sytuacja, w jakiej się znaleźli, popycha bohaterów Teffi do podjęcia najtrudniejszej decyzji. Młody inwalida z opowiadania Майскиũ жук (1924), który walczył w Armii Ochotniczej pod dowództwem Piotra Wrangla, głoduje, gdyż ze względu na swoje kalectwo nie może znaleźć pracy. Brak źródła utrzymania, pieniędzy i wsparcia, także ze strony rodaków, a przede wszystkim nadziei na lepsze jutro skłania go do popełnienia samobójstwa.

Autorka Pyłu diamentowego niejednokrotnie zwracała w swoich utworach uwagę na zamkniętość rosyjskiej kolonii, podkreślając przy tym nie tylko negatywne, lecz również pozytywne strony takiego sposobu bycia. Poczucie wspól- 
noty, przynależności do większej grupy pozwalało emigrantom przede wszystkim zachować świadomość narodową, co nabrało szczególnej wagi, gdy okazało się, że będą przebywać na wygnaniu dłuższy czas, a może nawet zostaną tu na zawsze. Wiarę $\mathrm{w}$ upadek reżimu bolszewickiego podkopało między innymi uznanie przez Francję istnienia Związku Radzieckiego w 1924 roku. Rosyjscy intelektualiści szybko uzmysłowili sobie swój obowiązek wobec przyszłych generacji, polegający na ocaleniu kultury i tradycyjnych wartości.

Przypadło im w udziale dożyć tej właśnie chwili, kiedy ojczyznę trzeba spakować w tobołki i wywieźć za granicę, żeby zachowała się dla nowych pokoleń - w nadziei, że w lepszych czasach, kiedy barbarzyńcy odstąpią lub przegrają, te nowe pokolenia wrócą do miejsc życia przodków i rozpakują wygnańcze tobołki, i znów zaczną żyć tak, jak się w tym miejscu żyło [Lis 2015: 77].

Jednakże najmłodsze pokolenie urodzone tuż przed rewolucją lub już na wygnaniu nierzadko odarte jest $\mathrm{z}$ tożsamości narodowej: przemieszcza się z kraju do kraju, mówi kilkoma językami, wszędzie czuje się jak w domu, a przy tym niewiele wie o ojczyźnie, bo rodzicom zajętym walką o przetrwanie nie zawsze zostaje czas, by przekazywać im wartości patriotyczne. Takim obywatelem świata jest kilkuletnia bohaterka opowiadania Под знаком валюты (1927). Na imię ma Chanum, ponieważ przyszła na świat w Konstantynopolu, a wypowiadając się, w jednym zdaniu łączy zazwyczaj leksykę rosyjską, francuską, angielską czy włoską, mieszkała już bowiem w różnych europejskich miastach. Ktoś zwraca nawet jej matce uwagę, że dziewczynka pozbawiona jest prawdziwej rodziny, ojczyzny i języka. Replika tej na pierwszy rzut oka niefrasobliwej kobiety dowodzi jednak, że figlarność to tylko poza: „ - Скажите , - ответила она, - если человека сбросили с Эйфелевой башни, очень ли для него важно, чтобы он, падая, успел по дороге хорошенько обдумать и взвесить свое положение?".

Natomiast starsza generacja, mimo deklarowanej dbałości o język ojczysty, zaczyna mówić osobliwym żargonem. Mieszaniną języka rosyjskiego i francuskiego lub niemieckiego posługują się między innymi bohaterowie miniatur Анна Степановна (1927) oraz Разговор (1925). W wykonaniu heroiny pierwszego opowiadania „Pola Elizejskie” to „Шан железе”, ,poczta pneumatyczna” „флегматичка”, a zwrot „do widzenia” - „A резервуap!”. Z kolei Iwan Pietrowicz i Nikołaj Siergiejewicz z drugiego utworu prowadzą dysputę o poprawności językowej i konieczności zachowania czystości języka rosyjskiego jako nośnika kultury, nie dostrzegają jednak, że sami wypaczają rodzimą mowę:

- Господи, да вы совсем по-русски говорить разучились. Ну, кто же говорит «в бецирке»?

- А как же по-русски?

- По-русски это называется арондисман. 
Wspomniane utwory świadczą o ważkości kwestii języka ojczystego w warunkach uchodźctwa tak dla Teffi, jak i całego środowiska literackiego. Pisarka nie bała się jednak parodiować w swych utworach licznych dyskusji na temat języka rosyjskiego, w których często uczestniczyła. Ponadto w szkiси О русском языке, który został opublikowany 19 grudnia 1926 roku w gazecie „Возрождение” wprost wyartykułowała myśl, że utrata ojczyzny pociąga za sobą utratę języka, ponieważ próba ocalenia języka, który jest zjawiskiem żywym, poprzez odwoływanie się jedynie do jego wzorców klasycznych, literackich zubaża go, zawęża [Сприридонова].

Reasumując, w na poły komicznych na poły tragicznych miniaturach Teffi lat 20., traktujących o losach zwykłych emigrantów, bo to właśnie głównie na nich skupiała uwagę pisarka, uchwycone zostały wszystkie aspekty życia rosyjskiej diaspory w Paryżu z jej nędzą, wyobcowaniem, samotnością, a nade wszystko tęsknotą za krajem ojczystym, która niekiedy dawała oparcie, często jednak odbierała chęć do działania.

\section{Bibliografia}

Зверев А. 2003. Повседневная жизнь русского литературного Парижа 1920-1940, źródło elektroniczne: http://royallib.com/book/zverev_aleksey/povsednievnaya_gizn_ russkogo_literaturnogo_pariga_19201940.html (dostęp 27.01.2016).

Меримерина М. А. 2009. Феномен ностальгии в теоретическом пространстве соицо-гуманитарных наук, "Аспирантский вестник Поволжья”, nr 1-2, s. 135-138.

Мяновска И. 2014. Пародийный пересказ Дон-Аминадо об эмигращии и эмигрантах, „Studia Rossica Posnaniensia", t. 39, s. 219-229.

Никоненко Ст., Несравненная Тэффи, [w:] Тэффи, Моя летопись, źródło elektroniczne: https:/ / coollib.com/b/248922/read (dostęp 18.08.2017).

Нитраур Э. 1989. «Жизнь смеется и плачет...». О судьбе и творчестве Тэффри, [w:] Тэффи, Ностальгия. Рассказы. Воспоминания, Ленинград: Художественная литература, s. 3-18.

Письма Н. А. Тэффи Дону Аминадо (А. П. Шполянскому). Публикация и комментарий Н. Ю. Желтовой. 2016. „Филологическая Регионалистика”, nr 2 (18), s. 60-64.

Спиридонова Л., Противление злу смехом. Н. Тэффи, źródło elektroniczne: http:// www.erudition.ru/referat/ref/id.57476_1.html (dostęp 15.06.2017).

Старостина С. А. 2010. Мотивный комплекс тоски по родине в мирике М. И. Цветаевой «берлинского» периода, „Социально-экономические явления и процессы”, $\operatorname{nr} 3$ (19), s. 308-313.

Тэффи. 1989. Ностальгия. Рассказы. Воспоминания, Ленинград: Художественная литература.

Тэффи Н. А. 2011. Собрание сочинений в пяти томах, t. III, Москва: Книжный клуб Книговек, źródło elektroniczne: http://ruslit.traumlibrary.net/page/teffy-ss05-03. html (dostęp 21.08.2017). 
Хрусталева Н.1999. Адаптация выходиев из бывшего СССР. Взгляд психолога, „Диаспоры”, nr 2-3, źródło elektroniczne: http://www.archipelag.ru/ru_mir/volni/4volna/ adaptation/ (dostęp 24.08.2017).

Lis R. 2015. W lodach Prowansji. Bunin na wygnaniu, Warszawa: Sic!

Mazurek H. 2014. Oczy w poetyckiej wyobraźni Mariny Cwietajewej, „Slavica Wratislaviensia", nr 158, s. 161-171.

Ndiaye I. A. 2007. Misja literatury emigracyjnej („pierwsza fala” emigracji rosyjskiej), "Acta Polono-Ruthenica", nr 12, s. 77-93.

Pietikainen P. 2015. Madness: A History, London-New York: Routledge Taylor \& Francis Group.

Sałajczykowa J. 2003. Prozaicy pierwszej fali emigracji rosyjskiej 1920-1940, Gdańsk: Wydawnictwo Uniwersytetu Gdańskiego.

Stownik wyrazów obcych. 1980. J. Tokarski (red.), Warszawa: PWN. 